Article

\title{
CuAlCe Oxides Issued from Layered Double Hydroxide Precursors for Ethanol and Toluene Total Oxidation
}

\author{
Hadi Dib, Rebecca El Khawaja ${ }^{\circledR}$, Guillaume Rochard * ${ }^{\mathbb{D}}$, Christophe Poupin ${ }^{\circledR}$, Stéphane Siffert \\ and Renaud Cousin * (D) \\ Univ. Littoral Côte d'Opale, U.R. 4492, UCEIV, Unité de Chimie Environnementale et Interactions sur le Vivant, \\ SFR Condorcet FR CNRS 3417, F-59140 Dunkerque, France; hadi.dib@univ-littoral.fr (H.D.); \\ rebecca.el-khawaja@univ-littoral.fr (R.E.K.); christophe.poupin@univ-littoral.fr (C.P.); \\ stephane.siffert@univ-littoral.fr (S.S.) \\ * Correspondence: guillaume.rochard@univ-littoral.fr (G.R.); renaud.cousin@univ-littoral.fr (R.C.)
}

Received: 1 July 2020; Accepted: 24 July 2020; Published: 3 August 2020

check for updates

\begin{abstract}
CuAlCe oxides were obtained from hydrotalcite-type precursors by coprecipitation using a $\mathrm{M}^{2+} / \mathrm{M}^{3+}$ ratio of 3 . The collapse of the layered double hydroxide structure following the thermal treatment leads to the formation of mixed oxides $\left(\mathrm{CuO}\right.$ and $\left.\mathrm{CeO}_{2}\right)$. The catalytic performance of the copper-based catalysts was evaluated in the total oxidation of two Volatile Organic Compounds (VOCs): ethanol and toluene. XRD, SEM Energy-Dispersive X-ray Spectrometry (EDX), $\mathrm{H}_{2}$-temperature programmed reduction (TPR) and XPS were used to characterize the physicochemical properties of the catalysts. A beneficial effect of combining cerium with $\mathrm{CuAl}-\mathrm{O}$ oxides in terms of redox properties and the abatement of the mentioned VOCs was demonstrated. The sample with the highest content of Ce showed the best catalytic properties, which were mainly related to the improvement of the reducibility of the copper species and their good dispersion on the surface. The presence of a synergetic effect between the copper and cerium elements was also highlighted.
\end{abstract}

Keywords: layered double hydroxide; catalytic oxidation; ethanol; toluene; VOC

\section{Introduction}

In the last few decades, extensive efforts have been focused on searching for methods of Volatile Organic Compound (VOC) abatement. VOCs produce ozone, which contributes to the formation of smog and global warming. The emission of these pollutants in the atmosphere is today, strictly regulated. For this, one of the most promising technologies is catalytic total oxidation, which represents an environmentally friendly control technology [1,2]. Studies of VOCs' catalytic oxidation have been widely reported [3-6]. Low temperatures (generally around $250-500{ }^{\circ} \mathrm{C}$ ) are required compared to thermal oxidation, which requires high temperatures $\left(650-1100^{\circ} \mathrm{C}\right)$. VOC oxidation has been carried out over noble metal and transition metal catalysts.

Noble metals are more active at low temperatures but are costly and often have low stability [7]. However, transition metal oxides (especially for Co-, Mn- and Cu-based catalysts) [8-10] can be cheaper alternatives to this kind of catalyst, which are known to be more resistant to poisoning. Cobalt-based catalysts have been highly reported in the literature as a great economical choice compared to noble metal catalysts $[7,11,12]$ but cause ethical problems because of their toxicity $[13,14]$. Manganese oxides have also been promising for the total oxidation of VOCs. However, they are most challenging to design due to having several oxidation states and multiple oxide polymorphs being found for every manganese oxidation state, each manifesting distinct catalytic performance for VOC oxidation $[15,16]$. Thus, a copper catalyst could be a good candidate for VOC oxidation. 
Moreover, Layered Double Hydroxides (LDH), named anionic clays or hydrotalcite-like materials, have been revealed to be interesting oxide precursors for the oxidation reaction. These consist of brucite-like $\mathrm{Mg}(\mathrm{OH})_{2}$ positively charged layers separated by an anionic layer compensating the positive charge, along with the water molecules trapped inside these layers. The most frequently occurring hydrotalcite (HT) compound is $\mathrm{Mg}_{6} \mathrm{Al}_{2}(\mathrm{OH})_{16} \mathrm{CO}_{3}, 4 \mathrm{H}_{2} \mathrm{O}$. A wide variety of $\mathrm{LDH}$ compounds are available due to the substitution of divalent and trivalent cations. After calcination, oxide materials are formed and show unique properties such as high surface area, thermal stability and well-mixed oxide homogeneity [8].

CuO-based catalysts present remarkable catalytic performance and selectivity for $\mathrm{CO}_{2}$ concerning the VOC oxidation reaction [17-19]. The feasibility of the partial substitution or total replacement of $\mathrm{Mg}^{2+}$ by $\mathrm{Cu}^{2+}$ is already described in the literature [20-22]. In previous work, Cu-based hydrotalcite-like compounds have gained significant interest, among the transition metals, due to their high efficiency as catalysts in some important processes such as the total oxidation of toluene [8]. Cerium oxide $\left(\mathrm{CeO}_{2}\right)$ is widely used as a promoter in various redox reactions due to its reducibility and its high oxygen storage capacity (OSC) $[23,24]$, which can improve the catalytic properties. A recent study has shown that the addition of cerium in the $\mathrm{CuAl}$ hydrotalcite-like material improves activity and selectivity towards NO selective catalytic reduction by lowering the temperature of carbon monoxide oxidation [25]. In addition, cerium incorporation has already been studied and tends to favor the reduction of metal cations in the catalyst based on mixed oxides prepared via the hydrotalcite route, which could lead to an increase in the catalytic activity [26]. Thus, in this work, a new and original approach is to combine cerium with $\mathrm{Cu}-\mathrm{Al}$ materials using the $\mathrm{LDH}$ synthesis approach.

This research work aims to synthesize $\mathrm{Cu}_{6} \mathrm{Al}_{2-x} \mathrm{Ce}_{\mathrm{x}}-\mathrm{O}$ catalysts using the hydrotalcite precursor to generate efficient catalytic systems for VOC abatement. Additionally, the effect of Ce content within the materials will be studied in catalytic $\mathrm{Cu}_{6} \mathrm{Al}_{2-\mathrm{x}} \mathrm{Ce}_{\mathrm{x}}-\mathrm{O}$ systems for the total oxidation of toluene (probe molecule of BTEX) and ethanol (probe molecule of oxygenated VOCs).

\section{Results}

\subsection{Structural Properties}

The XRD profiles of the hydrotalcite precursors before the calcination process are shown in Figure 1A. All the samples show the typical diffraction patterns of hydrotalcite-like materials, $\mathrm{Cu}_{6} \mathrm{Al}_{2}(\mathrm{OH})_{16} \mathrm{CO}_{3}, 4 \mathrm{H}_{2} \mathrm{O}$ (JCPDS-ICDD 37-0630). This result confirms that the hydrotalcite structure is retained even after cerium addition. $\mathrm{Cu}_{6} \mathrm{Al}_{2-\mathrm{x}} \mathrm{Ce}_{\mathrm{x}}-\mathrm{HT}$ materials also present pure ceria (JCPDS-ICDD 01-081-0792), which can be explained by the partial oxidation of $\mathrm{Ce}^{3+}$ cations to $\mathrm{Ce}^{4+}$ during the synthesis [27]. However, the increase in ceria addition leads to a gradual decrease in the intensities of each peak, indicating the loss of crystallinity of the corresponding phase. This might be due to the distortion of the brucite layers since $\mathrm{Ce}^{3+}$ ions have a larger ionic radius $(1.01 \AA)$ than $\mathrm{Al}^{3+}(0.54 \AA)$ [28]. Therefore, $\mathrm{Ce}^{3+}$ cations are probably not or partially incorporated in the hydrotalcite structure.

After a thermal treatment under air at $500{ }^{\circ} \mathrm{C}$ of the $\mathrm{Cu}_{6} \mathrm{Al}_{2-\mathrm{x}} \mathrm{Ce}_{\mathrm{x}}$-HT samples, XRD measurements were also performed on $\mathrm{Cu}_{6} \mathrm{Al}_{2-\mathrm{x}} \mathrm{Ce}_{\mathrm{x}}-\mathrm{O}$ samples. Following the thermal treatment, the collapse of the lamellar structure of hydrotalcite-like compounds leads to the formation of $\mathrm{CuO}$ oxides (JCPDS-ICDD 48-1548) and ceria (Figure 1B). For all of the samples analyzed, no peak corresponding to $\mathrm{Al}_{2} \mathrm{O}_{3}$ is observed, thus indicating that the aluminum species are in amorphous states [25]. However, no diffractions of $\mathrm{Cu}_{\mathrm{x}} \mathrm{Al}_{\mathrm{y}} \mathrm{O}_{4}$ spinel-like structures are obtained for any of the $\mathrm{Cu}_{6} \mathrm{Al}_{2-\mathrm{x}} \mathrm{Ce}-\mathrm{O}$ samples. This result could be related to the degree of crystallization of the spinel phases [21]. In fact, the evolution of X-ray diffractograms as a function of the calcination temperature $\left(60-1000{ }^{\circ} \mathrm{C}\right)$ for copper-based catalysts has been studied [20]. Since high calcination temperatures (above $800{ }^{\circ} \mathrm{C}$ ) are required for the formation of the $\mathrm{CuAl}_{2} \mathrm{O}_{4}$ spinel phase, no spinel-like structures are expected to be detected after a thermal treatment at $500{ }^{\circ} \mathrm{C}$. Moreover, the rate of the formation of the latter is greatly reduced for hydrotalcites with high copper contents caused by the decrease in the ions' diffusion in the presence of large particles of copper oxide [20,29]. 


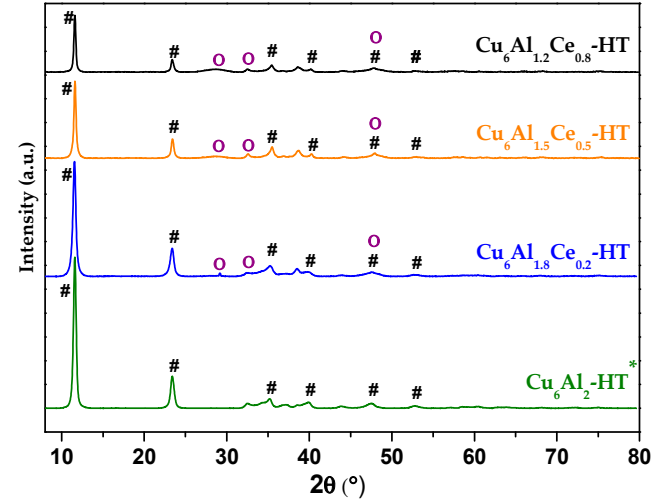

(A)

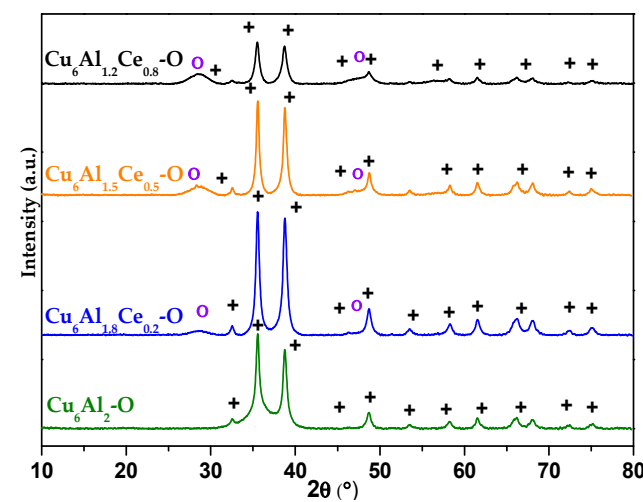

(B)

Figure 1. Diffraction patterns of the hydrotalcite precursors (A) and the mixed oxide samples (B) \#: $\mathrm{Cu}_{6} \mathrm{Al}_{2}(\mathrm{OH})_{16} \mathrm{CO}_{3}, 4 \mathrm{H}_{2} \mathrm{O}$; $+\mathrm{CuO} ; \mathrm{O}: \mathrm{CeO}_{2} ;{ }^{*}$ mitigated intensity.

In Table 1 , the $\mathrm{CuO}$ crystallite size is reported. When adding $\mathrm{Ce}$ in low amounts, the $\mathrm{CuO}$ crystallite size is not affected, while an increase in Ce content leads to the maximum $\mathrm{CuO}$ crystallite size $(20.7 \mathrm{~nm})$ and then a decrease to $15.2 \mathrm{~nm}$. Instead, the intensity of this phase decreases with an increase in the Ce content while the same amount of $\mathrm{Cu}$ is present in the materials. This can suggest that the addition of $\mathrm{Ce}$ allows the formation of amorphous $\mathrm{Cu}$ species instead of $\mathrm{CuO}$ crystals.

Table 1. Structural and textural features of the $\mathrm{Cu}_{6} \mathrm{Al}_{2-\mathrm{x}} \mathrm{Ce}_{\mathrm{x}}-\mathrm{O}$ samples.

\begin{tabular}{|c|c|c|c|c|c|}
\hline Samples & $\begin{array}{l}\text { CuO Crystallite } \\
\text { Size }(\mathrm{nm}) *\end{array}$ & $\begin{array}{l}\text { Experimental Atomic Ratio } \\
(\mathrm{Cu} / \mathrm{Al} / \mathrm{Ce}) * *\end{array}$ & $\begin{array}{l}\text { BET Surface Area } \\
\left(\mathrm{m}^{2} / \mathrm{g}\right)\end{array}$ & $\begin{array}{l}\text { Pore Diameter } \\
(\mathrm{nm})\end{array}$ & $\begin{array}{l}\text { Pore Volume } \\
\quad\left(\mathrm{cm}^{3} / \mathrm{g}\right)\end{array}$ \\
\hline $\mathrm{Cu}_{6} \mathrm{Al}_{1.2} \mathrm{Ce}_{0.8}-\mathrm{O}$ & 15.2 & $5.5 / 1.2 / 0.8$ & 47 & 17.3 & 0.19 \\
\hline $\mathrm{Cu}_{6} \mathrm{Al}_{1.5} \mathrm{Ce}_{0.5}-\mathrm{O}$ & 20.7 & $5.9 / 1.5 / 0.5$ & 37 & 22.7 & 0.22 \\
\hline $\mathrm{Cu}_{6} \mathrm{Al}_{2}-\mathrm{O}$ & 17.5 & $5.6 / 2.0 /-$ & 17 & 35.4 & 0.14 \\
\hline
\end{tabular}

\subsection{Textural Properties}

To understand the catalytic behavior, physicochemical characterizations of the oxide samples were performed. Nitrogen physisorption isotherms for all the $\mathrm{Cu}_{6} \mathrm{Al}_{2}-\mathrm{O}$ and $\mathrm{Cu}_{6} \mathrm{Al}_{2-\mathrm{x}} \mathrm{Ce}_{\mathrm{x}}-\mathrm{O}$ materials are represented in Figure 2. IV-type isotherms with H3-type hysteresis loops are observed for all samples, corresponding mostly to a mesoporous structure and narrow plate-like particles (IUPAC classification). The solids textural properties and chemical compositions are reported in Table 1. The chemical compositions are largely maintained especially the $\mathrm{Ce}$ and $\mathrm{Al}$ atomic ratio, while the $\mathrm{Cu}$ ratio seems slightly lower than the theoretical ratio. An increase in the Brunauer-Emmett-Teller (BET) surface area is revealed with an increase in Ce content in the materials. An increase in pore volume is observed when adding Ce to the materials, but no significant evolution is revealed upon an increase in Ce content in the materials. This observation could be explained by the progressive content of cerium oxide in the materials, which possess higher textural properties $\left(110 \mathrm{~m}^{2} \cdot \mathrm{g}^{-1}\right.$ and $0.5 \mathrm{~cm}^{3} \cdot \mathrm{g}^{-1}$ for $\mathrm{CeO}_{2}$ reference obtained via hydrothermal synthesis) than $\mathrm{CuO}$ and $\mathrm{Al}_{2} \mathrm{O}_{3}$.

The aim of using hydrotalcite-like precursors is to obtain a very good dispersion of the resulting metal oxides. In this context, the surface morphology of $\mathrm{Cu}_{6} \mathrm{Al}_{1.2} \mathrm{Ce}_{0.8}-\mathrm{O}$ was analyzed and is presented in Figure 3. A non-uniform and porous structure was observed upon SEM study, confirming the $\mathrm{N}_{2}$ physisorption results. However, the results of Energy-Dispersive X-ray Spectrometry (EDX) suggest a good dispersion of the elements $(\mathrm{Cu}, \mathrm{Al}$ and $\mathrm{Ce})$ based on an analysis of seven zones, randomly selected (Figure 4). These results confirm the advantages of the synthesis-by-hydrotalcite route in order to obtain homogeneous catalytic materials. It should be noted that Zedan et al. [18] synthesized Cu-Ce-O 
catalysts using the combustion method but the SEM-EDX results showed that these materials had a certain heterogeneity.

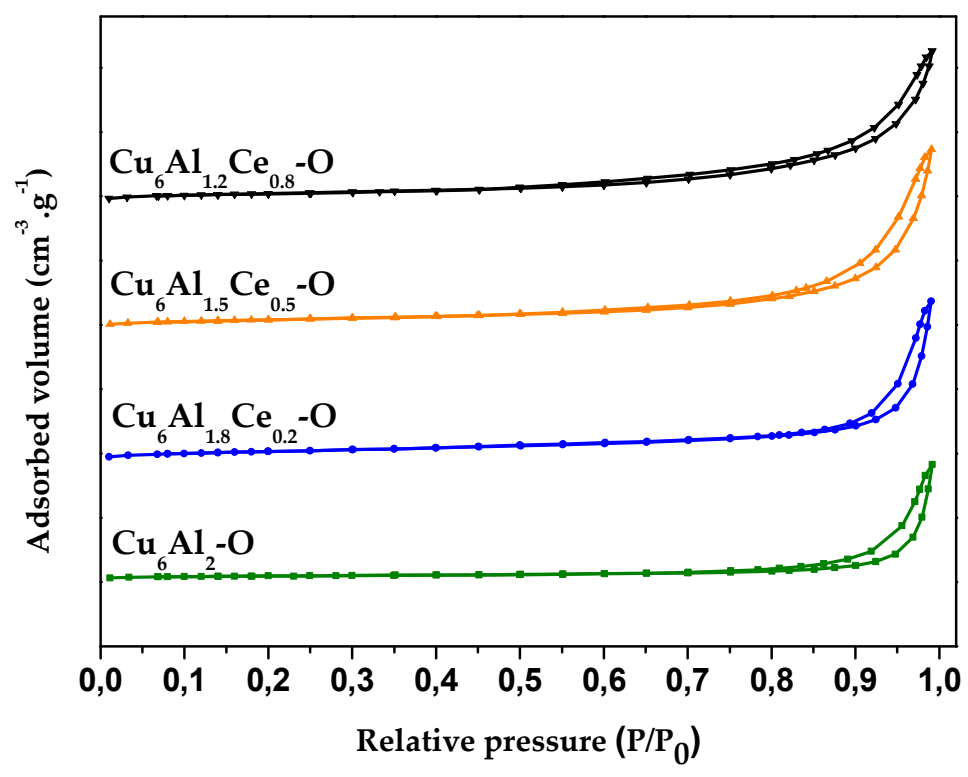

Figure 2. $\mathrm{N}_{2}$ adsorption/desorption isotherms of $\mathrm{Cu}_{6} \mathrm{Al}_{2-\mathrm{x}} \mathrm{Ce}_{\mathrm{x}}-\mathrm{O}$ samples.

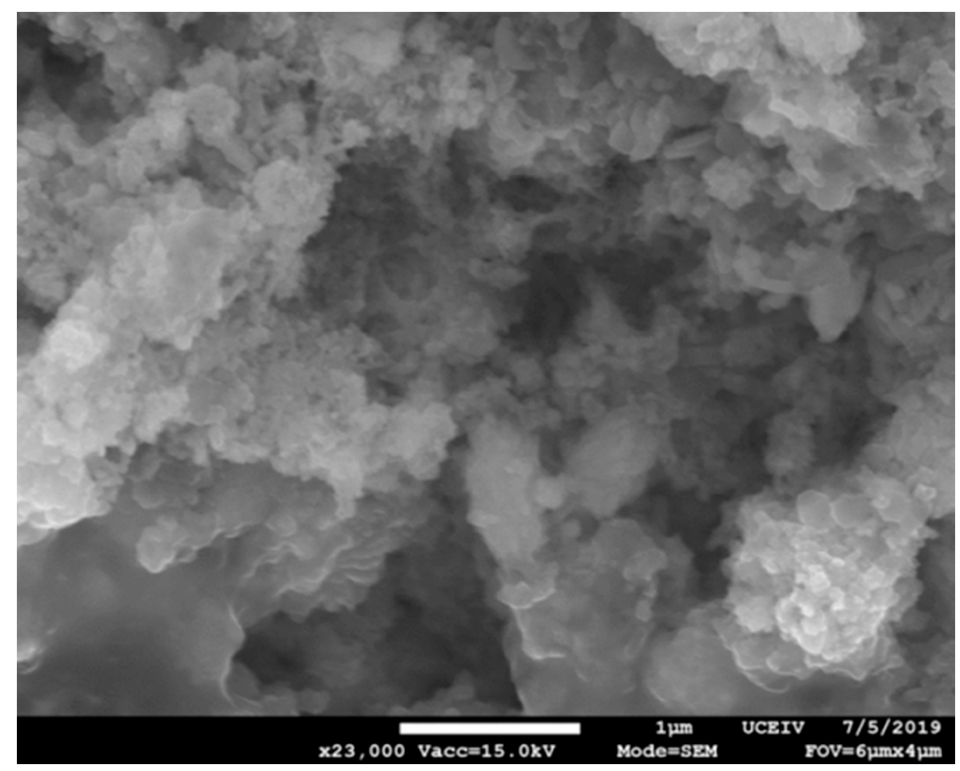

Figure 3. SEM image of $\mathrm{Cu}_{6} \mathrm{Al}_{1.2} \mathrm{Ce}_{0.8}-\mathrm{O}$ samples.

\section{3. $\mathrm{H}_{2}$-Temperature Programmed Reduction}

The $\mathrm{H}_{2}$-TPR profiles of simple, binary and ternary oxides are represented in Figure 5. As the samples have high copper contents, only signals obtained up to a reduction temperature of $350{ }^{\circ} \mathrm{C}$ and corresponding to the reduction of copper species were analyzed. The deconvolution of the TPR signals was carried out to assign the hydrogen reduction peaks. The $\mathrm{H}_{2}$ consumptions of $\alpha, \beta$ and $\gamma$ peaks (multi-peaks fitted according to the Gaussian method) are shown in Table 2. The reduction of copper species is only taken into consideration for the theoretical $\mathrm{H}_{2}$ consumption calculations. Copper oxide, $\mathrm{CuO}$, shows only one main peak at $290^{\circ} \mathrm{C}$ corresponding to the reduction of copper (from $\mathrm{Cu}^{2+}$ to $\left.\mathrm{Cu}^{0}\right)$ [22]. 

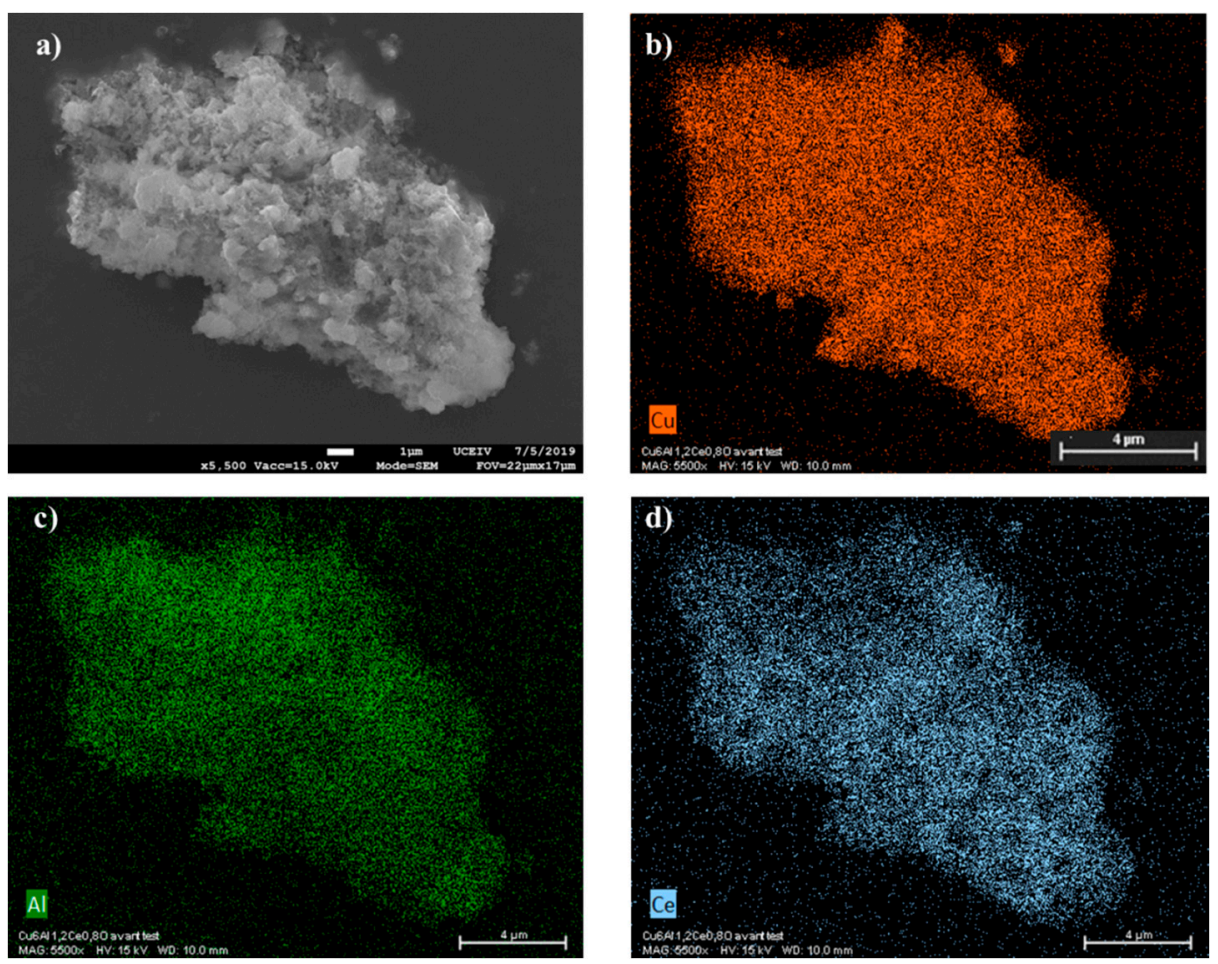

Figure 4. SEM images and element mapping of $\mathrm{Cu}_{6} \mathrm{Al}_{1.2} \mathrm{Ce}_{0.8}-\mathrm{O}$ sample.

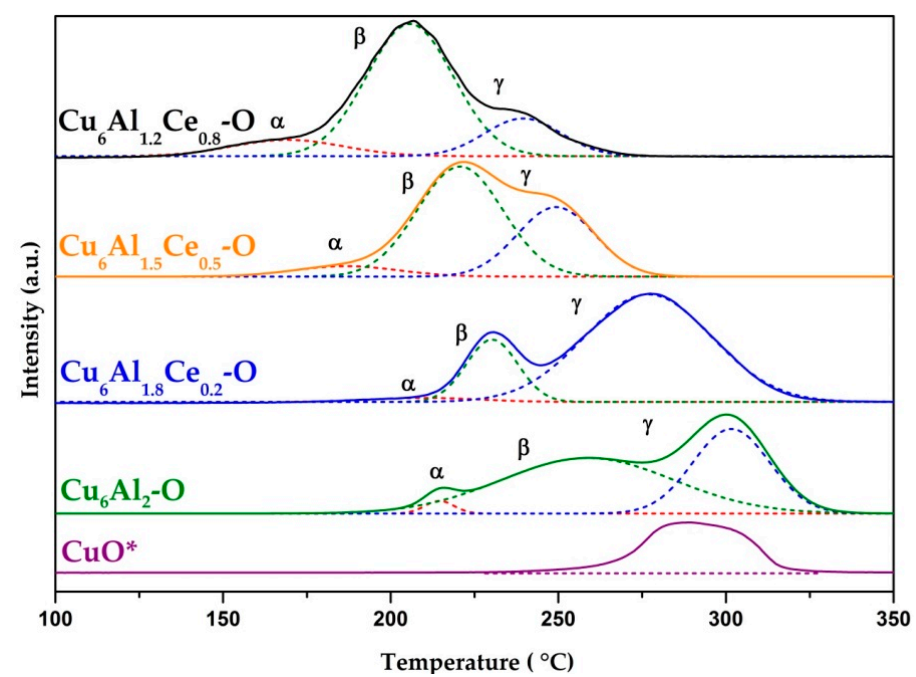

Figure 5. $\mathrm{H}_{2}$ - temperature programmed reduction (TPR) profiles of $\mathrm{CuO}$ and $\mathrm{Cu}_{6} \mathrm{Al}_{2-\mathrm{x}} \mathrm{Ce}_{\mathrm{x}}-\mathrm{O}$ samples.

Table 2. Reduction peak temperatures and $\mathrm{H}_{2}$ consumption for $\mathrm{Cu}_{6} \mathrm{Al}_{2-\mathrm{x}} \mathrm{Ce}_{\mathrm{x}}-\mathrm{O}$ samples.

\begin{tabular}{|c|c|c|c|c|c|c|}
\hline \multirow{2}{*}{ Samples } & \multicolumn{3}{|c|}{ Temperature $\left({ }^{\circ} \mathrm{C}\right)$} & \multicolumn{3}{|c|}{$\begin{array}{c}\mathrm{H}_{2} \text { Consumption }(\mu \mathrm{mol} / \mathrm{g}) \\
\left(\mathrm{T}<350^{\circ} \mathrm{C}\right)\end{array}$} \\
\hline & $\mathrm{T} \alpha$ & $\mathrm{T} \beta$ & $\mathrm{T} \gamma$ & Peak $\alpha$ & Peak $\beta$ & Peak $\gamma$ \\
\hline $\mathrm{CuO}$ & - & - & 289 & n.d * & n.d $*$ & n.d * \\
\hline $\mathrm{Cu} \mathrm{Al}_{1.2} \mathrm{Ce}_{0.8} \mathrm{O}$ & 168 & 206 & 239 & 942 & 6081 & 1542 \\
\hline $\mathrm{Cu} \mathrm{Al}_{1.5} \mathrm{Ce}_{0.5} \mathrm{O}$ & 187 & 221 & 249 & 590 & 4974 & 2866 \\
\hline $\mathrm{Cu}_{6} \mathrm{Al}_{1.8} \mathrm{Ce}_{0.2} \mathrm{O}$ & 210 & 230 & 277 & 263 & 1666 & 6838 \\
\hline $\mathrm{Cu}_{6} \mathrm{Al}_{2}-\mathrm{O}$ & 215 & 259 & 302 & 181 & 5235 & 3610 \\
\hline
\end{tabular}

* not determined. 
Regarding the mixed oxide $\mathrm{Cu}_{6} \mathrm{Al}_{2}-\mathrm{O}$, three reduction peaks $(\alpha, \beta$ and $\gamma)$ are observed. The $\alpha$ reduction peak located at a lower temperature is attributed to the reduction of $\mathrm{Cu}^{2+}$ ions highly dispersed on the surface. The $\beta$ reduction peak corresponds to the reduction of $\mathrm{CuO}$ cluster species. The $\gamma$ reduction peak, located at higher temperatures, is assigned to larger $\mathrm{CuO}$ bulk-like particles/crystalline $\mathrm{CuO}[22,30-32]$. The ceria-based samples present three reduction peaks $(\alpha, \beta$ and $\gamma)$, which correspond to the zones of the reduction of the copper species in interaction with cerium species. As shown in Table 2, the reduction temperature of these three peaks shifts to lower temperatures with the increase of ceria content. The redox properties improvement is attributed to the decrease in the crystallite size shown in XRD results previously. On the other hand, researchers suggest that a synergetic interaction between $\mathrm{CuO}$ and $\mathrm{CeO}_{2}$ could considerably improve the reducibility of the catalysts [33-35].

The $\mathrm{H}_{2}$ consumption (Table 2) of the $\alpha$ and $\beta$ peaks increases with the addition of $\mathrm{Ce}$ in the catalyst. Therefore, the Ce addition favors copper active species dispersion on the surface and promotes their reduction $[35,36]$. The decreasing consumption values of the $\gamma$ peak indicate the diminution of the $\mathrm{CuO}$ bulk-like proportion of particles. It can be concluded that $\mathrm{Ce}$ addition enhanced the transition from $\mathrm{CuO}$ bulk-like particles into $\mathrm{CuO}$ clusters while promoting the high dispersion of $\mathrm{Cu}^{2+}$ on the surface.

\subsection{X-ray Photoelectron Spectroscopy}

XPS was performed in order to gain more insight into the surface composition and the chemical state of the elements existing on the surface of $\mathrm{Cu}_{6} \mathrm{Al}_{2-x} \mathrm{Ce}_{x}-\mathrm{O}$ catalysts.

The $\mathrm{Cu} 2 \mathrm{p}$ photopeaks are presented in Figure S1. The $\mathrm{Cu} 2 \mathrm{p}$ spectra exhibit the principal peaks of $\mathrm{Cu} 2 \mathrm{p}_{3 / 2}$ and $\mathrm{Cu} 2 \mathrm{p}_{1 / 2}$ (centered at 934.4 and $954.2 \mathrm{eV}$, respectively) and shake-up satellite bands at $938-948 \mathrm{eV}$. No significant energy shift is observed with increasing Ce content. In line with the literature, it is reported that the higher $\mathrm{Cu} 2 \mathrm{p}_{3 / 2}$ binding energy and the satellite peak are two most important XPS characteristics of $\mathrm{Cu}^{2+}$ species. Meanwhile, the lower $\mathrm{Cu} 2 \mathrm{p}_{3 / 2}$ binding energy and absence of the shake-satellite peak are characteristic of reduced copper species $\left(\mathrm{Cu}^{+}\right.$and $\left.\mathrm{Cu}^{0}\right)[26,37,38]$. Thus, $\mathrm{Cu}$ species initially existing in these samples are mainly in divalent oxidation states $\left(\mathrm{Cu}^{2+}\right)$. Furthermore, the lack of band at lower apparent $\mathrm{Cu} 2 \mathrm{p}_{3 / 2}$ binding energy $(932.4 \mathrm{eV})$ demonstrates the absence of $\mathrm{Cu}^{+}$or $\mathrm{Cu}^{0}$ species in the catalysts. According to Table 3, an increase in the $\mathrm{nCu} / \mathrm{nM}$ atomic ratio as function of $\mathrm{Ce}$ content is noticeable. The presence of cerium in catalyst can then increase the dispersion of copper species on the surface and therefore promote their reductions. This can be directly linked to the formation of smaller particles of $\mathrm{CuO}$ reported in the reduction part.

Table 3. Summarized XPS results from Ce 3d, O 1s spectra and atomic ratios.

\begin{tabular}{|c|c|c|c|c|c|c|}
\hline \multirow{2}{*}{ Samples } & \multirow{2}{*}{ B.E. * Ce 3d u"'/eV } & \multirow{2}{*}{$\mathrm{Ce}^{\mathrm{III}} / \mathrm{Ce}^{\mathrm{IV}}$} & \multicolumn{2}{|c|}{ B.E. * O 1s/eV (\%) } & \multirow{2}{*}{$\mathrm{nCu} / \mathrm{nM}^{* *}$} & \multirow{2}{*}{ nO/nTot $* * *$} \\
\hline & & & O-I & O-II & & \\
\hline $\mathrm{Cu}_{6} \mathrm{Al}_{1.2} \mathrm{Ce}_{0.8}-\mathrm{O}$ & 917.1 & 0.11 & $530.2(26.1 \%)$ & $532.6(73.9 \%)$ & 0.48 & 0.81 \\
\hline $\mathrm{Cu}_{6} \mathrm{Al}_{1.5} \mathrm{Ce}_{0.5}-\mathrm{O}$ & 916.8 & 0.13 & $530.0(23.0 \%)$ & $532.0(77.0 \%)$ & 0.39 & 0.47 \\
\hline $\mathrm{Cu}_{6} \mathrm{Al}_{1.8} \mathrm{Ce}_{0.2}-\mathrm{O}$ & 916.4 & 0.36 & $529.8(17.9 \%)$ & $531.8(82.1 \%)$ & 0.33 & 0.57 \\
\hline $\mathrm{Cu}_{6} \mathrm{Al}_{2}-\mathrm{O}$ & - & - & $530.3(24.0 \%)$ & $532.2(76.0 \%)$ & 0.65 & 0.56 \\
\hline
\end{tabular}

${ }^{*}$ Binding energy. ${ }^{* *} \mathrm{nM}=\mathrm{nCu}+\mathrm{nAl}+\mathrm{nCe} .{ }^{* *} \mathrm{nTot}=\mathrm{nO}+\mathrm{nCu}+\mathrm{nAl}+\mathrm{nCe}$.

The Ce $3 \mathrm{~d}$ spectra are presented in Figure S2, and the corresponding binding energies are assembled in Table 3. The Ce 3d spectra can be deconvoluted into ten peaks (Figure 6) with six components for $\mathrm{Ce}^{\mathrm{IV}}\left(\mathrm{u}^{\prime \prime \prime} / \mathrm{v}^{\prime \prime} / \mathrm{u}^{\prime \prime} / \mathrm{v}^{\prime \prime} / \mathrm{u} / \mathrm{v}\right)$ and four components for $\mathrm{C} \mathrm{e}^{\mathrm{III}}\left(\mathrm{u}^{\prime} / \mathrm{v}^{\prime} / \mathrm{u}^{0} / \mathrm{v}^{0}\right)$. This indicates a combination of $\mathrm{Ce}^{3+}$ and $\mathrm{Ce}^{4+}$ ions within the catalysts $[26,32]$. The ratio $\mathrm{Ce} \mathrm{e}^{\mathrm{III}} / \mathrm{Ce}^{\mathrm{IV}}$ (Table 3 ) decreased upon increasing the amount of $\mathrm{Ce}$ in the composition of the mixed oxide. Therefore, a partial substitution of $\mathrm{Al}^{3+}$ by $\mathrm{Ce}^{3+}$ is possible at low concentrations of $\mathrm{Ce}$. This substitution can be less significant when this concentration increases, leading to the formation of $\mathrm{CeO}_{2}$, which can explain the abundance of the $\mathrm{Ce}^{4+}$ proportion and the improvement of the textural properties.

The Al 2p photoemission spectra for the studied samples are shown in Figure 7. Three peaks can be distinguished in each spectrum. Two broad-centered peaks at 84.5 and $77.5 \mathrm{eV}$ are attributed to the 
$\mathrm{Cu} 3 \mathrm{p}$ signal, while the shoulder peak at lower energy $(74.2 \mathrm{eV})$ represents the $\mathrm{Al} 2 \mathrm{p}$ signal. The $\mathrm{Al}^{3+}$ cations are characteristic of the octahedral species present in alumina oxides, $\mathrm{Al}_{2} \mathrm{O}_{3}$ [39]. As expected, the signal and the appropriate atomic percentage of $\mathrm{Al}$ decreased with the $\mathrm{Ce}$ content, while the $\mathrm{Cu}$ signal remained approximatively the same. No modifications of $\mathrm{Al}$ valence occurred with the addition of Ce.

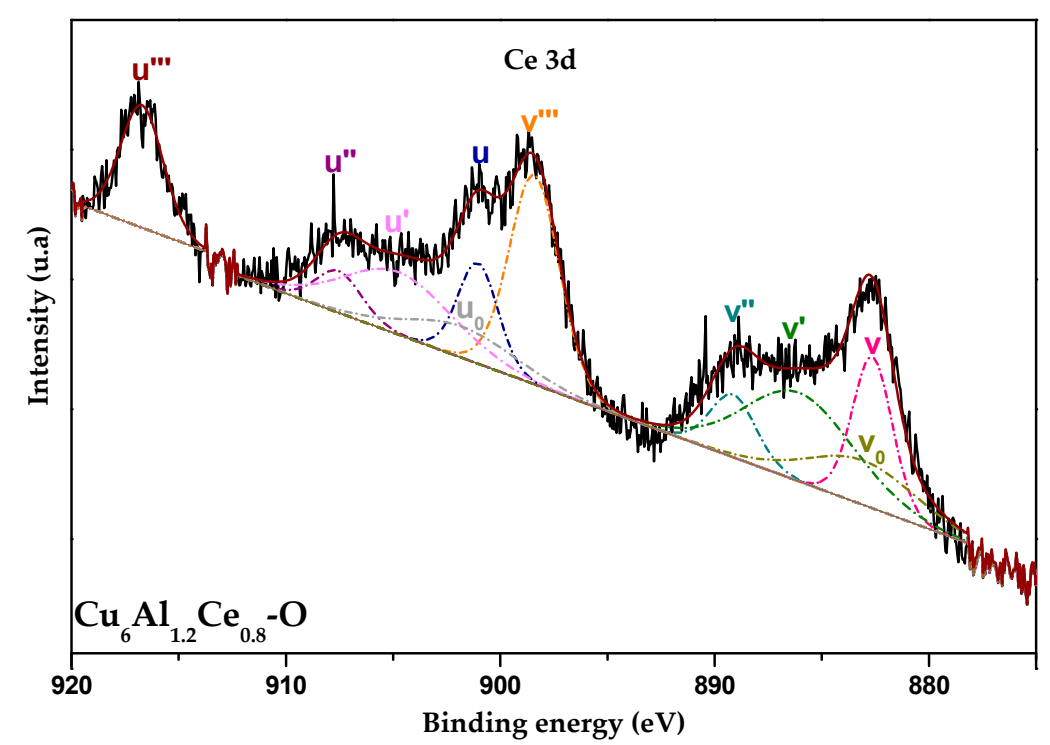

Figure 6. Fitted curve of $\mathrm{Ce} 3 \mathrm{~d}$ spectrum for $\mathrm{Cu}_{6} \mathrm{Al}_{1.2} \mathrm{Ce}_{0.8}-\mathrm{O}$ sample.

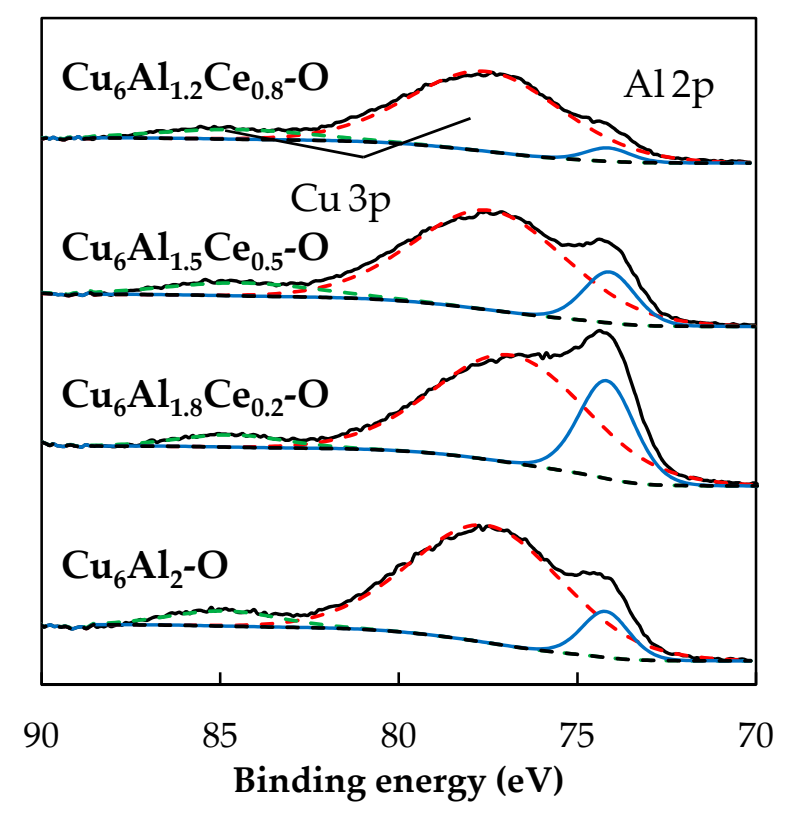

Figure 7. $\mathrm{Al} 2 \mathrm{p}$ photopeaks of $\mathrm{Cu}_{6} \mathrm{Al}_{2-\mathrm{x}} \mathrm{Ce}_{\mathrm{x}}-\mathrm{O}$ samples.

The XPS spectra of $\mathrm{O} 1 \mathrm{~s}$ are shown in Figure 8. Two photopeaks are distinct in the $\mathrm{O} 1 \mathrm{~s}$ region at 530 (O-I) and $532 \mathrm{eV}(\mathrm{O}-\mathrm{II})$. O-II can be related to the oxygen of the surface hydroxyl or carbonate species $[18,40,41]$, while O-I is related to the lattice oxygen of the metal oxide [19,40-42]. The binding energy and relative percentage of each photopeak are presented in Table 3. The lattice oxygen abundance increased progressively for the compounds with high Ce contents. This can be supported by the decline in the $\mathrm{Ce} \mathrm{III}^{\mathrm{II}} \mathrm{Ce}^{\mathrm{IV}}$ ratio presented previously and can also be attributed to the increase in the global valence of the metal oxide. 


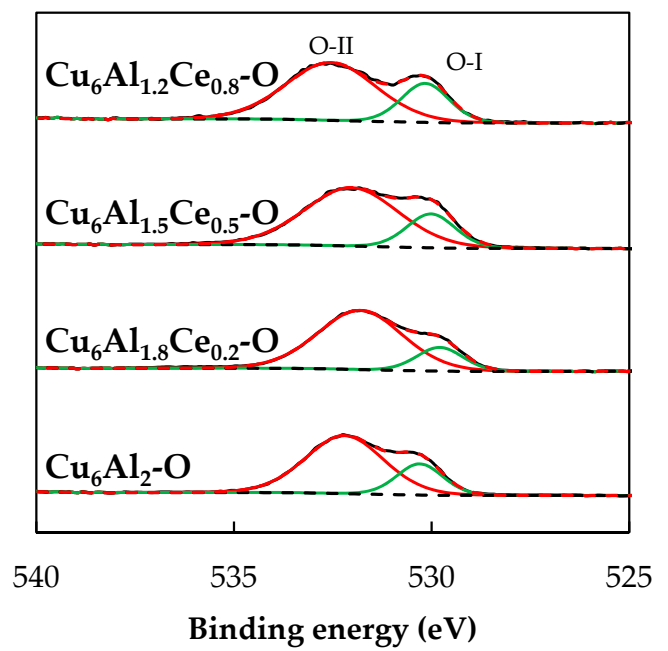

Figure 8. $\mathrm{O} 1 \mathrm{~s}$ photopeaks of $\mathrm{Cu}_{6} \mathrm{Al}_{2-\mathrm{x}} \mathrm{Ce}_{\mathrm{x}}-\mathrm{O}$ samples.

\subsection{Catalytic Performance}

Figure 9A shows the toluene conversion curves in the $150-400{ }^{\circ} \mathrm{C}$ range using the synthesized $\mathrm{Cu}_{6} \mathrm{Al}_{2-\mathrm{x}} \mathrm{Ce}_{\mathrm{x}}-\mathrm{O}$ materials. The catalytic behavior has been compared to that of $\mathrm{CuO}$ and $\mathrm{CeO}_{2}$ pure oxides in terms of $\mathrm{T}_{50}$, which represents the temperature when $50 \%$ conversion is obtained. It can be seen that the toluene conversion into $\mathrm{CO}_{2}$ increased with the rise in the ceria incorporation in catalytic materials. $\mathrm{Cu}_{6} \mathrm{Al}_{2-\mathrm{x}} \mathrm{Ce}_{\mathrm{x}}-\mathrm{O}$ catalysts improved the reaction conversion in the following order: $\mathrm{Cu}_{6} \mathrm{Al}_{1.2} \mathrm{Ce}_{0.8}-\mathrm{O} \cong \mathrm{Cu}_{6} \mathrm{Al}_{1.5} \mathrm{Ce}_{0.5}-\mathrm{O}>\mathrm{CeO}_{2}>\mathrm{Cu}_{6} \mathrm{Al}_{1.8} \mathrm{Ce}_{0.2}-\mathrm{O}>\mathrm{Cu}_{6} \mathrm{Al}_{2}-\mathrm{O}>\mathrm{CuO}$. The reaction pathway of toluene oxidation is mostly initiated by an attack on the methyl group, with subsequent oxidation steps. Thus, during toluene oxidation, formation of $\mathrm{CO}$ and/or benzene could be observed. However, with our catalysts, no formation of those by-products was detected, except in the case of the $\mathrm{CeO}_{2}$ catalyst as mentioned in Figure S3.

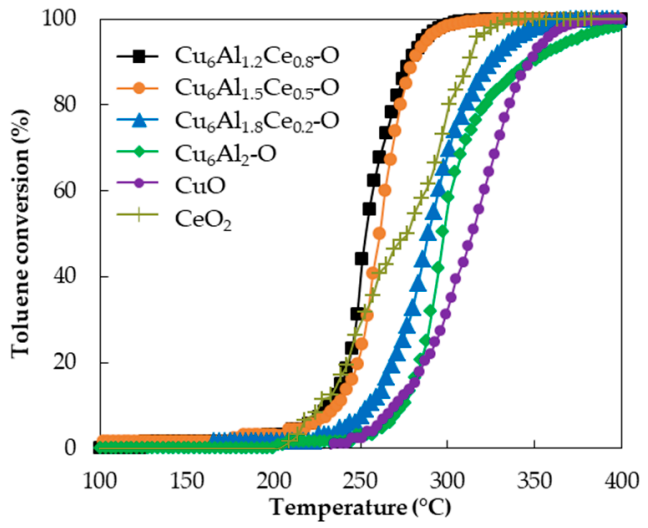

(A)

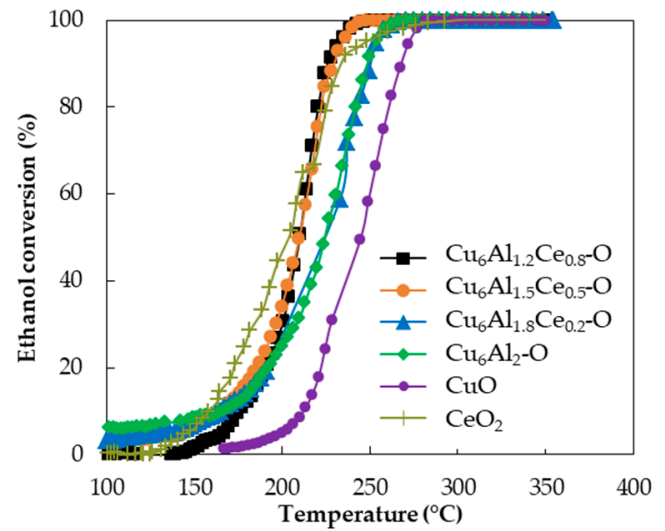

(B)

Figure 9. Light-off curves of toluene (A) and ethanol (B) total oxidation.

A similar trend is distinguished for the total oxidation of ethanol (Figure 9B). $\mathrm{Cu}_{6} \mathrm{Al}_{2-\mathrm{x}} \mathrm{Ce}_{\mathrm{x}}-\mathrm{O}$ achieved complete ethanol conversion at lower temperatures than the binary catalyst $\mathrm{Cu}_{6} \mathrm{Al}_{2}-\mathrm{O}$ and the referenced pure oxides. The results on ceria-based catalysts indicate that the activity increases with an increase in Ce content, where $\mathrm{Cu}_{6} \mathrm{Al}_{1.2} \mathrm{Ce}_{0.8}-\mathrm{O}$ and $\mathrm{Cu}_{6} \mathrm{Al}_{1.5} \mathrm{Ce}_{0.5}-\mathrm{O}$ exhibit the highest catalytic activity $\left(\mathrm{T}_{50}=220^{\circ} \mathrm{C}\right)$. On the other hand, the formation of acetaldehyde as a major by-product was detected in the chromatographic analysis. This latter is, however, completely oxidized at a temperature 
20-30 ${ }^{\circ} \mathrm{C}$ higher than the temperature for the $100 \%$ conversion of ethanol. After that, $\mathrm{CO}_{2}$ and water are the main products that remain at the end of the reaction.

In order to compare the catalysts, the temperature that allows $50 \%$ of VOC conversion $\left(T_{50}\right)$ is reported in Table 4. Moreover, the comparison of the $\mathrm{Cu}_{6} \mathrm{Al}_{2-\mathrm{x}} \mathrm{Ce}_{\mathrm{x}}-\mathrm{O}$ catalysts is shown in Figure 10, as a function of the $\mathrm{Ce} \mathrm{e}^{\mathrm{III}} / \mathrm{Ce}^{\mathrm{IV}}$ ratio (Figure 10A), percentage of O-I and O-II (Figure 10B) determined by XPS analysis, and the $\mathrm{H}_{2}$ consumption of the $\alpha$ and $\beta$ peaks (Figure 11) determined from $\mathrm{H}_{2}$-TPR analysis.

Table 4. Summary of catalytic properties of $\mathrm{Cu}_{6} \mathrm{Al}_{2-\mathrm{x}} \mathrm{Ce}_{\mathrm{x}}-\mathrm{O}$.

\begin{tabular}{ccc}
\hline \multirow{2}{*}{ Samples } & \multicolumn{2}{c}{$\mathbf{T}_{\mathbf{5 0}}\left({ }^{\circ} \mathbf{C}\right)$} \\
& Toluene & Ethanol \\
\hline $\mathrm{Cu}_{6} \mathrm{Al}_{1.2} \mathrm{Ce}_{0.8}-\mathrm{O}$ & 254 & 210 \\
$\mathrm{Cu}_{6} \mathrm{Al}_{1.5} \mathrm{Ce}_{0.5}-\mathrm{O}$ & 261 & 210 \\
$\mathrm{Cu}_{6} \mathrm{Al}_{1.8} \mathrm{Ce}_{0.2}-\mathrm{O}$ & 286 & 230 \\
\hline
\end{tabular}

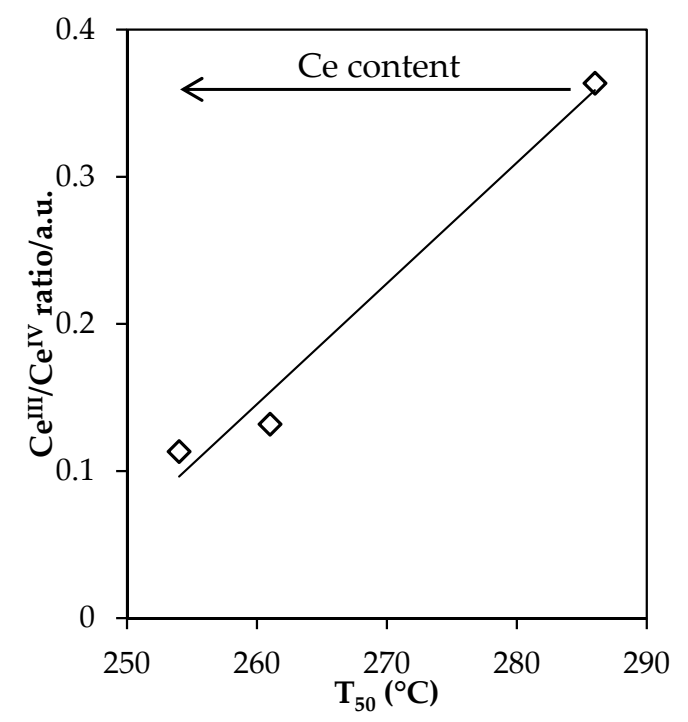

(A)

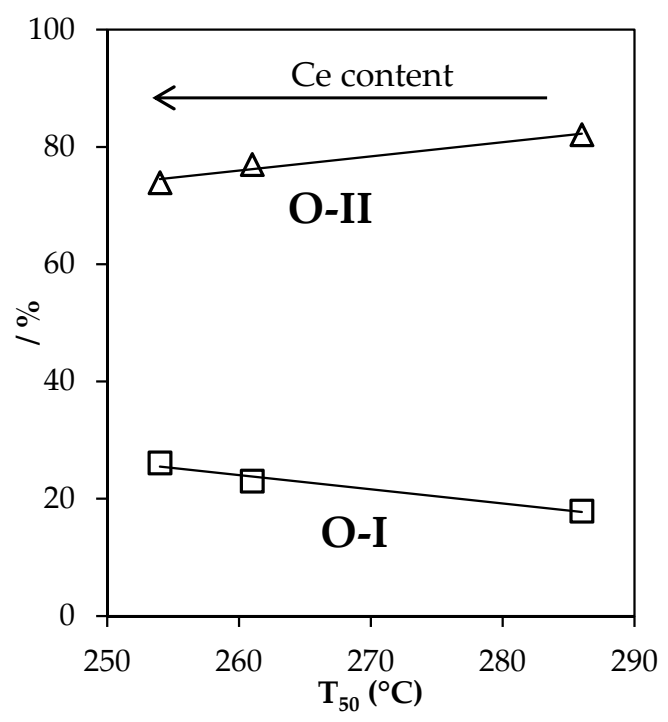

(B)

Figure 10. Evolution of XPS data ((A): $\mathrm{Ce}^{\mathrm{IV}} / \mathrm{Ce}^{\mathrm{III}}$ ratio, (B): \%O-I and \%O-II) with $\mathrm{T}_{50}$ for toluene oxidation reaction.

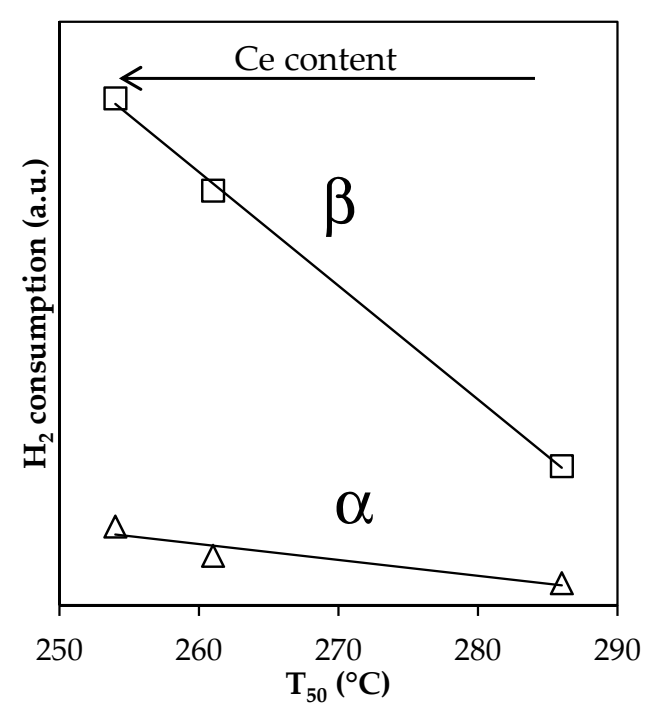

Figure 11. Evolution of $\mathrm{H}_{2}$-TPR data with $\mathrm{T}_{50}$ for toluene oxidation reaction. 
A correlation is noticed between the $\mathrm{T}_{50}$ of the catalysts in the total oxidation of toluene and the $\mathrm{Ce}^{\mathrm{III}} / \mathrm{Ce}^{\mathrm{IV}}$ ratio obtained by XPS analysis (Figure 10A). However, no significant correlation is shown with $\mathrm{nCu} / \mathrm{nM}$ ratio.

In order to determine which kind of oxygen is mainly related to the studied reactions, Figure 10B shows that an increase in the \%O-I is well connected with a lower $\mathrm{T}_{50}$ in the toluene oxidation reaction. The $\% \mathrm{O}-\mathrm{I}$ increased linearly with the decrease in $\mathrm{T}_{50}$, while the $\% \mathrm{O}-\mathrm{II}$ decreased. The reaction seems to be favored by a higher concentration of O-I at the surface. The lattice oxygen favors the reaction pathway via the Mars-Van Krevelen mechanism where it is directly involved as a reactive oxygen species. The lattice oxygen can thus positively contribute to and enhance the VOC oxidation. This finding is also related to the increase in the Ce-content that forces the lattice oxygen to migrate to the surface. Thus, despite the relatively low surface area of the synthesized catalysts, the catalytic activity will be enhanced. The correlation between the $\mathrm{T}_{50}$ and the $\mathrm{H}_{2}$-consumption of the different peak observed in the $\mathrm{H}_{2}$-TPR experiment is reported in Figure 11. As described above, in terms of redox properties, an increase in the consumption of $\mathrm{H}_{2}$ of the $\alpha$ and $\beta$ peaks (attributed to the reduction of smaller particles of $\mathrm{CuO}$ ) is observed with increasing Ce content. The consumption of $\alpha$ and $\beta$ peaks increased with a decrease in $\mathrm{T}_{50}$, while the $\gamma$ peak's consumption decreased (not presented here). The formation of a smaller cluster of $\mathrm{CuO}$ in interaction with ceria oxide and the diminution of larger particles of $\mathrm{CuO}$ seem to be the most advantageous for the activity of toluene oxidation. The presence of cerium in the copper catalyst can increase the dispersion of the copper species on the surface of the $\mathrm{Cu}_{6} \mathrm{Al}_{2-\mathrm{x}} \mathrm{Ce}-\mathrm{O}$ catalysts and therefore promote their reductions. It also assures a better availability and mobility of oxygen on the surface of the solid. This promotes the oxygen exchange with the well-dispersed copper species. In fact, this active phase could be reduced during the toluene oxidation and re-oxidized with oxygen released from the ceria. This synergistic effect between cerium and copper is a key factor for good catalytic activity in the toluene oxidation reaction.

Concerning ethanol oxidation, no correlation has been observed between $\mathrm{T}_{50}$ and the formation of $\mathrm{CuO}$ clusters. An optimum $\mathrm{T}_{50}$ in ethanol oxidation is obtained with $\mathrm{Cu}_{6} \mathrm{Al}_{1.5} \mathrm{Ce}_{0.5}-\mathrm{O}$ catalysts (same $\mathrm{T}_{50}$ as $\mathrm{Cu}_{6} \mathrm{Al}_{1.2} \mathrm{Ce}_{0.8}-\mathrm{O}$ with less $\mathrm{Ce}$ ). It corresponds to the catalysts with the higher $\mathrm{CuO}$ crystallite size. It can be suggested that for the ethanol oxidation reaction, the active site is different from the toluene oxidation reaction site and present in bigger $\mathrm{CuO}$ crystallites.

The catalytic performances of $\mathrm{Cu}_{6} \mathrm{Al}_{1.2} \mathrm{Ce}_{0.8}-\mathrm{O}$ materials are compared to the performances of supported noble metals and $\mathrm{Cu}$-Ce catalysts in the literature in toluene and ethanol oxidation, based on $\mathrm{T}_{50}$ (Table 5). Concerning the toluene reaction, the $\mathrm{T}_{50}$ of our catalysts is higher than the one obtained with $\mathrm{Pd} /-\mathrm{Al}_{2} \mathrm{O}_{3}$ [43]. That was expected for supported noble metals, but in the presence of those catalysts, the formation of $\mathrm{CO}$ and/or by-products such as benzene is possible [43]. However, using our catalyst, no formations of $\mathrm{CO}$ or benzene are detected. Compared to the CoAlCe-O [43] catalyst, a similar $\mathrm{T}_{50}$ is obtained by replacing $\mathrm{Cu}$ with $\mathrm{Co}$. For $\mathrm{Cu}-\mathrm{Ce}[23,44]$ catalysts, the $\mathrm{T}_{50}$ is lower than in this work. This could be explained by the higher proportion of $\mathrm{Ce}$ in those materials. Concerning the oxidation of ethanol, the $\mathrm{T}_{50}$ of our catalyst is $210^{\circ} \mathrm{C}$. The same $\mathrm{T}_{50}$ has been obtained with a higher content of Ce in those materials too [23]. Thus, our materials, which contain less cerium, are just as effective.

Table 5. Comparison of catalyst performances.

\begin{tabular}{cccc}
\hline \multirow{2}{*}{ Catalyst } & \multicolumn{2}{c}{$\mathbf{T}_{\mathbf{5 0}}\left({ }^{\circ} \mathbf{C}\right)$} & \multirow{2}{*}{ Ref. } \\
& Toluene & Ethanol & \\
\hline $\mathrm{Pd} / \mathrm{Al}_{2} \mathrm{O}_{3}$ & 218 & & {$[43]$} \\
$\mathrm{CoAlCe}-\mathrm{O}$ & 249 & & {$[43]$} \\
$\mathrm{Cu}_{0.3} \mathrm{Ce}_{0.7}$ & 187 & & {$[44]$} \\
$\mathrm{Cu}_{0.15} \mathrm{Ce}_{0.85}$ & 230 & 210 & {$[23]$} \\
$\mathrm{Ce} \mathrm{CuCoMgAl} \mathrm{Mu}_{1.2} \mathrm{Ce}_{0.8}-\mathrm{O}$ & 254 & 262 & {$[45]$} \\
$\mathrm{Cu}_{6} \mathrm{Al}_{1.2}$ & 210 & This work \\
\hline
\end{tabular}




\section{Materials and Methods}

\subsection{Catalyst Synthesis}

The copper-based hydrotalcite-like compounds, $\mathrm{Cu}_{6} \mathrm{Al}_{2-\mathrm{x}} \mathrm{Ce}_{\mathrm{x}}-\mathrm{HT}$, were synthesized by a coprecipitation method. The corresponding ratio of $\mathrm{M}^{2+} / \mathrm{M}^{3+}$ used was equal to 3. A solution containing appropriate quantities of $\mathrm{Cu}\left(\mathrm{NO}_{3}\right)_{2}, 3 \mathrm{H}_{2} \mathrm{O}$ (PanReac Quimica, Barcelona, Spain), $\mathrm{Al}\left(\mathrm{NO}_{3}\right)_{3}, 9 \mathrm{H}_{2} \mathrm{O}$ (Chem Lab, Zedelgem, Belgium ) and $\mathrm{Ce}\left(\mathrm{NO}_{3}\right)_{3}, 6 \mathrm{H}_{2} \mathrm{O}$ (Chem Lab, Zedelgem, Belgium) was added dropwise, under vigorous stirring, into $\mathrm{NaOH}$ (PanReac Quimica, Barcelona, Spain, 98\%) (2 mol. $\mathrm{L}^{-1}$ ) and $\mathrm{Na}_{2} \mathrm{CO}_{3}$ ( Thermo Fisher Scientific, New Jersey, USA, 99\%) $\left(1 \mathrm{~mol} . \mathrm{L}^{-1}\right)$ solution. The $\mathrm{pH}$ was maintained at 10.5 for $18 \mathrm{~h}$ at room temperature. The precipitate was then filtered, washed several times with hot deionized water $\left(60^{\circ} \mathrm{C}\right)$ and dried at $60^{\circ} \mathrm{C}$ for $48 \mathrm{~h}$. Three hydrotalcite-like compounds with different ratios were synthesized: $\mathrm{Cu}_{6} \mathrm{Al}_{2-\mathrm{x}} \mathrm{Ce}_{\mathrm{x}} \mathrm{HT}$ with $\mathrm{x}=0,0.2,0.5$ and 0.8. $\mathrm{The}^{\circ} \mathrm{Cu}_{6} \mathrm{Al}_{2-\mathrm{x}} \mathrm{Ce} \mathrm{e}_{\mathrm{x}} \mathrm{O}$ were obtained after the thermal treatment of $\mathrm{HT}$ at $500^{\circ} \mathrm{C}\left(1^{\circ} \mathrm{C} \cdot \mathrm{min}^{-1}\right)$ for $4 \mathrm{~h}$ under an air flow of 33 mL.min ${ }^{-1}$.

Copper oxides (99\%) were purchased from Fluka Company. The coprecipitation of $\left(\mathrm{Ce}\left(\mathrm{NO}_{3}\right)_{3}\right.$, $\left.6 \mathrm{H}_{2} \mathrm{O}\right)$ in $\mathrm{NaOH}$ solution results in the formation of cerium hydroxide $\mathrm{Ce}(\mathrm{OH})_{4} . \mathrm{CuO}$ and $\mathrm{CeO}_{2}$ were used after calcination under air flow at 500 and $400{ }^{\circ} \mathrm{C}$ during $4 \mathrm{~h}$, respectively.

\subsection{Catalyst Characterization}

The crystallinity of the hydrotalcite and calcined catalysts was analyzed at room temperature by X-ray diffraction analysis using a Bruker D8 Advance X-Ray Diffractometer (AXS) (Bruker, Champs-Sur-Marne, France) equipped with $\mathrm{CuK} \alpha$ radiation $(\lambda=1.5418 \AA$ ) and a Lynx Eye Detector. The measurements were performed from $5^{\circ}$ to $80^{\circ}$ with a step size $\Delta(2 \theta)=0.02^{\circ}$ and a counting time of 2 seconds per step.

The textural properties of all the calcined samples were determined using $\mathrm{N}_{2}$ adsorption/desorption isotherms carried out using Micromeritics ASAP 2020 (Micromeritics, Norcross, USA). Prior to each analysis, the samples were degassed under vacuum for $2 \mathrm{~h}$ at $300^{\circ} \mathrm{C}$. The specific surface area was estimated using the Brunauer-Emmett-Teller (BET) equation, while the pore diameter and specific pore volume were obtained according to the Barrett-Joyner-Halenda (BJH) model.

$\mathrm{H}_{2}$-temperature programmed reduction $\left(\mathrm{H}_{2}\right.$-TPR) studies were carried out using an AMI-200 instrument (Labor und Analysen Technik $\mathrm{GmbH}$, Garbsen, Germany) equipped with a TCD detector. First, the calcined samples $(30 \mathrm{mg})$ were treated in Ar flow $\left(30 \mathrm{~mL} \cdot \mathrm{min}^{-1}\right)$ at $150{ }^{\circ} \mathrm{C}$ for $60 \mathrm{~min}$. After cooling, the reduction of the solid was carried out in a 5 vol. $\% \mathrm{H}_{2} / \mathrm{Ar}$ gas mixture $\left(20 \mathrm{~mL} . \mathrm{min}^{-1}\right)$ while heating from 150 to $900{ }^{\circ} \mathrm{C}$ (ramping rate: $5^{\circ} \mathrm{C} \cdot \mathrm{min}^{-1}$ ).

X-ray Photoelectron Spectroscopy (XPS) (Kratos, Manchester, U.K.) spectra were recorded using monochromatic $\mathrm{Al} \mathrm{K} \alpha(1486.6 \mathrm{eV})$ radiation at an operating source power of $13 \mathrm{kV}$ and $10 \mathrm{~mA}$. The hemispherical energy analyzer with a constant pass energy mode $\mathrm{Ep}=50 \mathrm{eV}$ was used in all measurements. The binding energy (BE) was calibrated based on the line position of $C 1 \mathrm{~s}(284.8 \mathrm{eV})$. The core-level spectra were decomposed into components with mixed Gaussian-Lorentzian lines using a subtraction of the Shirley-type background using the CasaXPS software (Casa Software Ltd. Teignmouth, UK).

The elemental compositions of the samples were analyzed using an Inductively Coupled Plasma-Optical Emission Spectrometer, ICP-OES (Thermo fisher, iCAP 6300 DUO) (Waltham, MA, USA), equipped with a charge injection device. Prior to the analysis, $50 \mathrm{mg}$ of catalyst was dissolved into aqua regia $\left(\mathrm{HNO}_{3} / \mathrm{HCl} 1: 2\right)$ under microwaving for $30 \mathrm{~min}$. The solution was then topped up to $50 \mathrm{~mL}$ with ultrapure water, diluted to $10 \%$ and filtered with a $0.45 \mu \mathrm{m}$ cellulosic microfilter.

Scanning Electron Microscopy was performed with a JEOL JSM-711F (JEOL, Tokyo, Japan) apparatus equipped with an Energy-Dispersive X-ray Spectrometer (MEB-EDX). The calcined samples were adhered on aluminum stubs and then coated with a thin film of chromium. 


\subsection{Catalytic Activity Tests}

Toluene and ethanol oxidations were carried out in a continuous-flow fixed-bed reactor loaded with $100 \mathrm{mg}$ (35-45 mesh) of catalyst at atmospheric pressure. The gas mixture composed of $1000 \mathrm{ppm}$ of VOC in air was passed through the reactor with a flow rate of $100 \mathrm{~mL} \cdot \mathrm{min}^{-1}$, which corresponds to a gas hourly space velocity (GHSV) of about $30.000 \mathrm{~h}^{-1}$. Before each test, the catalysts were preactivated at $300^{\circ} \mathrm{C}$ for $1 \mathrm{~h}$ under flowing air $\left(33 \mathrm{~mL} \cdot \mathrm{min}^{-1}\right)$.

For the toluene oxidation, the inlet and outlet gas stream concentrations were analyzed with a micro-gas chromatographer (Agilent 490MicroGC) coupled to an infrared analyzer (ADEV CO $2-\mathrm{CO}$ Analyzer Model 4400IR) for $\mathrm{CO}_{2}$ and $\mathrm{CO}$ analysis.

However, the reactants and the products of the oxidation of ethanol were analyzed using a micro-gas chromatographer (Varian CP- 4900) coupled to a Pfeiffer Vacuum OmniStar Quadrupole Mass Spectrometer (QMS-200).

\section{Conclusions}

$\mathrm{A} \mathrm{Cu}_{6} \mathrm{Al}_{2-\mathrm{x}} \mathrm{Ce}_{\mathrm{x}}-\mathrm{O}$ catalytic system with different $\mathrm{Ce}$ contents was successfully synthesized via a hydrotalcite route. The characterization of the products showed favorable physico-chemical and catalytic properties of the $\mathrm{Cu}_{6} \mathrm{Al}_{2-\mathrm{x}} \mathrm{Ce}_{\mathrm{x}}-\mathrm{O}$ materials with Ce contents starting from $\mathrm{x}=0.5$. A homogeneous dispersion of $\mathrm{Cu}, \mathrm{Al}$ and $\mathrm{Ce}$ species was distinguished for these materials. $\mathrm{H}_{2}$-TPR suggests that combining Ce with the copper-based catalysts favors the dispersion of copper active species on the surface and promotes their reduction. XPS analysis confirmed the presence of $\mathrm{Ce}^{3+}, \mathrm{Ce}^{4+}$ and $\mathrm{Al}^{3+}$ species on the surface of the $\mathrm{Cu}_{6} \mathrm{Al}_{2-\mathrm{x}} \mathrm{Ce}_{\mathrm{x}}-\mathrm{O}$ samples, as well as the formation of copper $\mathrm{Cu}^{2+}$ species that would interact with cerium. The addition of Ce can favor a better dispersion of $\mathrm{CuO}$ particles on the surface of the materials. The catalyst with the best catalytic performance was found to be the one with the highest $\mathrm{Ce}$ content. The good catalytic activity for the total oxidation of toluene and ethanol of $\mathrm{Cu}_{6} \mathrm{Al}_{1.2} \mathrm{Ce}_{0.8}-\mathrm{O}$ can be attributed to the high surface area, the good metal dispersion, the high proportion of $\mathrm{Ce}^{\mathrm{IV}}$ and the high reducibility of the copper species on the surface. Thus, combining cerium with $\mathrm{CuAl}$ oxides using the $\mathrm{LDH}$ synthesis approach permits efficient catalysts to be obtained. A synergetic effect between copper and cerium species occurs and is favorable for the abatement of VOCs. The improvement of the textural, structural and redox properties of the oxides can lead to the enhancement of the catalytic performance for VOC oxidation.

Supplementary Materials: The following are available online at http://www.mdpi.com/2073-4344/10/8/870/s1. Figure S1: $\mathrm{Cu} 2 \mathrm{p}$ photopeaks of $\mathrm{Cu}_{6} \mathrm{Al}_{2-x} \mathrm{Ce} \mathrm{e}_{\mathrm{x}}-\mathrm{O}$ samples. Figure S2: Ce $3 \mathrm{~d}$ photopeaks of $\mathrm{Cu}_{6} \mathrm{Al}_{2-\mathrm{x}} \mathrm{Ce}_{\mathrm{x}}-\mathrm{O}$ samples.

Author Contributions: Conceptualization, R.C. and G.R.; methodology, R.C. and C.P.; validation, C.P. and S.S.; formal analysis, H.D. and R.E.K.; investigation, H.D., R.E.K. and G.R.; data curation, R.E.K. and G.R.; writing—original draft preparation, G.R.; writing—review and editing, R.C.; visualization, C.P.; supervision, R.C.; funding acquisition, R.C. and S.S.; All authors have read and agreed to the published version of the manuscript.

Funding: The authors gratefully acknowledge the financial support from the CPER-IRENE program ("COVO" project), the Hauts-de-France region and the European Community (Interreg V France-Wallonie-Vlaanderen project, "DepollutAir").

Conflicts of Interest: The authors declare no conflict of interest.

\section{References}

1. Huang, H.; Xu, Y.; Feng, Q.; Leung, D.Y.C. Low temperature catalytic oxidation of volatile organic compounds: A review. Catal. Sci. Technol. 2015, 5, 2649-2669. [CrossRef]

2. Torres, J.Q.; Royer, S.; Bellat, J.P.; Giraudon, J.M.; Lamonier, J.F. Formaldehyde: Catalytic oxidation as a promising soft way of elimination. ChemSusChem 2013, 6, 578-592. [CrossRef]

3. Brunet, J.; Genty, E.; Landkocz, Y.; Zallouha, M.A.; Billet, S.; Courcot, D.; Siffert, S.; Thomas, D.; De Weireld, G.; Cousin, R. Identification of by-products issued from the catalytic oxidation of toluene by chemical and biological methods. C. R. Chim. 2015, 18, 1084-1093. [CrossRef]

4. Santos, V.P.; Pereira, M.F.R.; Órfão, J.J.M.; Figueiredo, J.L. Mixture effects during the oxidation of toluene, ethyl acetate and ethanol over a cryptomelane catalyst. J. Hazard. Mater. 2011, 185, 1236-1240. [CrossRef] 
5. Wu, H.; Wang, L.; Zhang, J.; Shen, Z.; Zhao, J. Catalytic oxidation of benzene, toluene and p-xylene over colloidal gold supported on zinc oxide catalyst. Catal. Commun. 2011, 12, 859-865. [CrossRef]

6. Burgos, N.; Paulis, M.; Mirari Antxustegi, M.; Montes, M. Deep oxidation of VOC mixtures with platinum supported on Al2O3/Al monoliths. Appl. Catal. B Environ. 2002, 38, 251-258. [CrossRef]

7. Liotta, L.F.; Ousmane, M.; Di Carlo, G.; Pantaleo, G.; Deganello, G.; Boreave, A.; Giroir-Fendler, A. Catalytic removal of toluene over Co3O4-CeO 2 mixed oxide catalysts: Comparison with Pt/Al2O 3. Catal. Lett. 2009, 127, 270-276. [CrossRef]

8. Genty, E.; Cousin, R.; Capelle, S.; Gennequin, C.; Siffert, S. Catalytic oxidation of toluene and CO over nanocatalysts derived from hydrotalcite-like compounds (X 62+ $\mathrm{Al} 23+)$ : Effect of the bivalent cation. Eur. J. Inorg. Chem. 2012, 2802-2811. [CrossRef]

9. Busca, G.; Daturi, M.; Finocchio, E.; Lorenzelli, V.; Ramis, G.; Willey, R.J. Transition metal mixed oxides as combustion catalysts: Preparation, characterization and activity mechanisms. Catal. Today 1997, 33, 239-249. [CrossRef]

10. Sekine, Y.; Nishimura, A. Removal of formaldehyde from indoor air by passive type air-cleaning materials. Atmos. Environ. 2007, 35, 2001-2007. [CrossRef]

11. Trigueiro, F.E.; Ferreira, C.M.; Volta, J.C.; Gonzalez, W.A.; de Oliveria, P.G.P. Effect of niobium addition to $\mathrm{Co} / \gamma-\mathrm{Al} 2 \mathrm{O} 3$ catalyst on methane combustion. Catal. Today 2006, 118, 425-432. [CrossRef]

12. Garcia, T.; Agouram, S.; Sánchez-Royo, J.F.; Murillo, R.; Mastral, A.M.; Aranda, A.; Vázquez, I.; Dejoz, A.; Solsona, B. Deep oxidation of volatile organic compounds using ordered cobalt oxides prepared by a nanocasting route. Appl. Catal. A Gen. 2010, 386, 16-27. [CrossRef]

13. Papageorgiou, I.; Brown, C.; Schins, R.; Singh, S.; Newson, R.; Davis, S.; Fisher, J.; Ingham, E.; Case, C.P. The effect of nano- and micron-sized particles of cobalt-chromium alloy on human fibroblasts in vitro. Biomaterials 2007, 28, 2946-2958. [CrossRef] [PubMed]

14. Chattopadhyay, S.; Dash, S.K.; Tripathy, S.; Das, B.; Mandal, D.; Pramanik, P.; Roy, S. Toxicity of cobalt oxide nanoparticles to normal cells; An in vitro and in vivo study. Chem. Biol. Interact. 2015, 226, 58-71. [CrossRef] [PubMed]

15. Zhou, L.; He, J.; Zhang, J.; He, Z.; Hu, Y.; Zhang, C.; He, H. Facile in-situ synthesis of manganese dioxide nanosheets on cellulose fibers and their application in oxidative decomposition of formaldehyde. J. Phys. Chem. C 2011, 115, 16873-16878. [CrossRef]

16. Sekine, Y. Oxidative decomposition of formaldehyde by metal oxides at room temperature. Atmos. Environ. 2002, 36, 5543-5547. [CrossRef]

17. Kim, S.C. The catalytic oxidation of aromatic hydrocarbons over supported metal oxide. J. Hazard. Mater. 2002, 91, 285-299. [CrossRef]

18. Zedan, A.F.; Polychronopoulou, K.; Asif, A.; AlQaradawi, S.Y.; AlJaber, A.S. Cu-Ce-O catalyst revisited for exceptional activity at low temperature CO oxidation reaction. Surf. Coat. Technol. 2018, 354, 313-323. [CrossRef]

19. Zhang, X.; Zhang, X.; Song, L.; Hou, F.; Yang, Y.; Wang, Y.; Liu, N. Enhanced catalytic performance for $\mathrm{CO}$ oxidation and preferential $\mathrm{CO}$ oxidation over $\mathrm{CuO} / \mathrm{CeO} 2$ catalysts synthesized from metal organic framework: Effects of preparation methods. Int. J. Hydrogen Energy 2018, 43, 18279-18288. [CrossRef]

20. Alejandre, A.; Medina, F.; Salagre, P.; Correig, X.; Sueiras, J.E. Preparation and study of Cu-Al mixed oxides via hydrotalcite-like precursors. Chem. Mater. 1999, 11, 939-948. [CrossRef]

21. Kannan, S.; Rives, V.; Knözinger, H. High-temperature transformations of Cu-rich hydrotalcites. J. Solid State Chem. 2004, 177, 319-331. [CrossRef]

22. Teixeira, C.D.O.P.; Montani, S.D.S.; Palacio, L.A.; Zotin, F.M.Z. The effect of preparation methods on the thermal and chemical reducibility of $\mathrm{Cu}$ in Cu-Al oxides. Dalton Trans. 2018, 47, 10989-11001. [CrossRef] [PubMed]

23. Delimaris, D.; Ioannides, T. VOC oxidation over $\mathrm{CuO}-\mathrm{CeO} 2$ catalysts prepared by a combustion method. Appl. Catal. B Environ. 2009, 89, 295-302. [CrossRef]

24. Heynderickx, P.M.; Thybaut, J.W.; Poelman, H.; Poelman, D.; Marin, G.B. The total oxidation of propane over supported $\mathrm{Cu}$ and Ce oxides: A comparison of single and binary metal oxides. J. Catal. 2010, 272, 109-120. [CrossRef]

25. Qian, J.; Hou, X.; Wang, F.; Hu, Q.; Yuan, H.; Teng, L.; Li, R.; Tong, Z.; Dong, L.; Li, B. Catalytic reduction of $\mathrm{NO}$ by $\mathrm{CO}$ over promoted $\mathrm{Cu} 3 \mathrm{Ce} 0.2 \mathrm{Al} 10.8$ composite oxides derived from hydrotalcite-like Compounds. J. Phys. Chem. C 2018, 122, 2097-2106. [CrossRef] 
26. Chen, C.; Wang, R.; Shen, P.; Zhao, D.; Zhang, N. Inverse CeO2/CuO catalysts prepared from heterobimetallic metal-organic framework precursor for preferential $\mathrm{CO}$ oxidation in H2-rich stream. Int. J. Hydrogen Energy 2015, 40, 4830-4839. [CrossRef]

27. Genty, E.; Dib, H.; Brunet, J.; Poupin, C.; Siffert, S.; Cousin, R. Effect of Ce Addition on mgal mixed oxides for the total oxidation of CO and toluene. Top. Catal. 2019, 62, 397-402. [CrossRef]

28. Sharma, M.K.; Melesse, S.F. Optimal block designs for CDC experiments method (2). Metron 2011, 69, 297-307. [CrossRef]

29. Alejandre, A.; Medina, F.; Rodriguez, X.; Salagre, P.; Sueiras, J.E. Preparation and activity of copper, nickel and copper-nickel-al mixed oxides via hydrotalcite-like precursors for the oxidation of phenol aqueous solutions. Stud. Surf. Sci. Catal. 2000, 130 B, 1763-1768. [CrossRef]

30. Dow, W.P.; Wang, Y.P.; Huang, T.J. TPR and XRD studies of yttria-doped ceria $/ \gamma$-alumina-supported copper oxide catalyst. Appl. Catal. A Gen. 2000, 190, 25-34. [CrossRef]

31. Guo, X.; Zhou, R. A new insight into the morphology effect of ceria on $\mathrm{CuO} / \mathrm{CeO} 2$ catalysts for $\mathrm{CO}$ selective oxidation in hydrogen-rich gas. Catal. Sci. Technol. 2016, 6, 3862-3871. [CrossRef]

32. Cecilia, J.A.; Arango-Díaz, A.; Marrero-Jerez, J.; Núñez, P.; Moretti, E.; Storaro, L.; Rodríguez-Castellón, E. Catalytic behaviour of $\mathrm{CuO}-\mathrm{CeO} 2$ systems prepared by different synthetic methodologies in the CO-PROX reaction under CO2-H2O feed stream. Catalysts 2017, 7, 160. [CrossRef]

33. Qi, L.; Yu, Q.; Dai, Y.; Tang, C.; Liu, L.; Zhang, H.; Gao, F.; Dong, L.; Chen, Y. Influence of cerium precursors on the structure and reducibility of mesoporous $\mathrm{CuO}-\mathrm{CeO} 2$ catalysts for $\mathrm{CO}$ oxidation. Appl. Catal. B Environ. 2012, 119-120, 308-320. [CrossRef]

34. Sun, S.; Mao, D.; Yu, J.; Yang, Z.; Lu, G.; Ma, Z. Lowerature CO oxidation on $\mathrm{CuO} / \mathrm{CeO} 2$ catalysts: The significant effect of copper precursor and calcination temperature. Catal. Sci. Technol. 2015, 5, 3166-3181. [CrossRef]

35. Sumrunronnasak, S.; Chanlek, N.; Pimpha, N. Improved CeCuOx catalysts for toluene oxidation prepared by aqueous cationic surfactant precipitation method. Mater. Chem. Phys. 2018, 216, 143-152. [CrossRef]

36. Deng, C.; Li, B.; Dong, L.; Zhang, F.; Fan, M.; Jin, G.; Gao, J.; Gao, L.; Zhang, F.; Zhou, X. NO reduction by CO over $\mathrm{CuO}$ supported on $\mathrm{CeO} 2-$ doped TiO2: The effect of the amount of a few CeO2. Phys. Chem. Chem. Phys. 2015, 17, 16092-16109. [CrossRef]

37. Biesinger, M.C. Advanced analysis of copper X-ray photoelectron spectra. Surf. Interface Anal. 2017, 49, 1325-1334. [CrossRef]

38. Du, L.; Wang, W.; Yan, H.; Wang, X.; Jin, Z.; Song, Q.; Si, R.; Jia, C. Copper-ceria sheets catalysts: Effect of copper species on catalytic activity in CO oxidation reaction. J. Rare Earths 2017, 35, 1186-1196. [CrossRef]

39. Khassin, A.A.; Yurieva, T.M.; Kaichev, V.V.; Bukhtiyarov, V.I.; Budneva, A.A.; Paukshtis, E.A.; Parmon, V.N. Metal-support interactions in cobalt-aluminum co-precipitated catalysts: XPS and CO adsorption studies. J. Mol. Catal. A Chem. 2001, 175, 189-204. [CrossRef]

40. Cheng, J.; Yu, J.; Wang, X.; Li, L.; Li, J.; Hao, Z. Novel CH4 combustion catalysts derived from Cu-Co/X-Al $(\mathrm{X}=\mathrm{Fe}, \mathrm{Mn}, \mathrm{La}, \mathrm{Ce})$ hydrotalcite-like compounds. Energy Fuels 2008, 22, 2131-2137. [CrossRef]

41. Bai, Y.; Bian, X.; Wu, W. Catalytic properties of $\mathrm{CuO} / \mathrm{CeO} 2-\mathrm{A} 12 \mathrm{O} 3$ catalysts for low concentration $\mathrm{NO}$ reduction with CO. Appl. Surf. Sci. 2019, 463, 435-444. [CrossRef]

42. Chang, Z.; Zhao, N.; Liu, J.; Li, F.; Evans, D.G.; Duan, X.; Forano, C.; De Roy, M. CuCeO mixed oxides from Ce-containing layered double hydroxide precursors: Controllable preparation and catalytic performance. J. Solid State Chem. 2011, 184, 3232-3239. [CrossRef]

43. Brunet, J.; Genty, E.; Barroo, C.; Cazier, F.; Poupin, C.; Siffert, S.; Thomas, D.; De Weireld, G.; de Bocarmé, T.V.; Cousin, R. The CoAlCeO mixed oxide: An alternative to palladium-based catalysts for total oxidation of industrial VOCs. Catalysts 2018, 8. [CrossRef]

44. He, C.; Yu, Y.; Yue, L.; Qiao, N.; Li, J.; Shen, Q.; Yu, W.; Chen, J.; Hao, Z. Low-temperature removal of toluene and propanal over highly active mesoporous $\mathrm{CuCeOx}$ catalysts synthesized via a simple self-precipitation protocol. Appl. Catal. B Environ. 2014, 147, 156-166. [CrossRef]

45. Pérez, A.; Montes, M.; Molina, R.; Moreno, S. Cooperative effect of Ce and Pr in the catalytic combustion of ethanol in mixed $\mathrm{Cu} / \mathrm{CoMgAl}$ oxides obtained from hydrotalcites. Appl. Catal. A Gen. 2011, 408, 96-104. [CrossRef]

(C) 2020 by the authors. Licensee MDPI, Basel, Switzerland. This article is an open access article distributed under the terms and conditions of the Creative Commons Attribution (CC BY) license (http://creativecommons.org/licenses/by/4.0/). 